\title{
Structural Shifts in the Chinese Software Industry
}

Nir Kshetri, University of North Carolina at Greensboro

\section{The Chinese \\ commercial \\ software industry, although lagging behind India's, has recently been undergoing major structural shifts that could make it the Asian industry leader.}

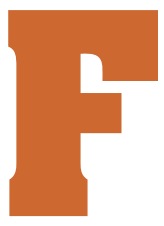
ollowing the post-1978 economic and political reforms that provided incentives for private and foreign investments, China has left India behind in terms of almost all economic and technological indicators. Between 1980 and 2002, China's per capita gross domestic product (GDP) increased from US\$134 to $\$ 960$, while India's increased from $\$ 262$ to $\$ 470$ (see table 1). From 1978 to 2003, China's inward foreign direct investment exceeded $\$ 400$ billion. ${ }^{1}$ In the 1990s, India's share in

world trade grew from 0.5 to 0.7 percent, while China's share rose steeply from 1.8 to 4.0 percent. In 2001, China's total exports were $\$ 259$ billion, compared to India's $\$ 40$ billion. China's fixed-telephone and PC penetration rates are over four times greater than India's, and cell phone penetration is over 13 times greater (see table 1).

Yet China has failed to catch up with India in one area: commercial software. This industry is very important for developing countries such as China and India because it can be started with much less investment than manufacturing industries.

The gap between the two countries' software industries is substantial. India's software exports exceeded $\$ 12$ billion in 2003, compared to China's $\$ 2$ billion. Global software industry analysts disagree, however, as to this gap's future direction. Some, including the president of India's National Association of Software and Service Companies (NASSCOM), believe that China lacks the skills and manpower it needs to catch up in the race. ${ }^{17} \mathrm{An}$ other school of thought maintains that China's status as a regional and potentially global economic superpower and its leadership in the electronics industry will help to close the gap. A Gartner Group study, for instance, suggests that by shifting technological gears, China could catch up with India in commercial software by $2006 .{ }^{18}$

What will be the magnitude and the direction of the gap between the two nations' software industries in the future? Given that China and India account for two-fifths of the world population and are among the few developing countries that have established good track records in exporting high-technology products, this question is important. While 


\section{Table 1}

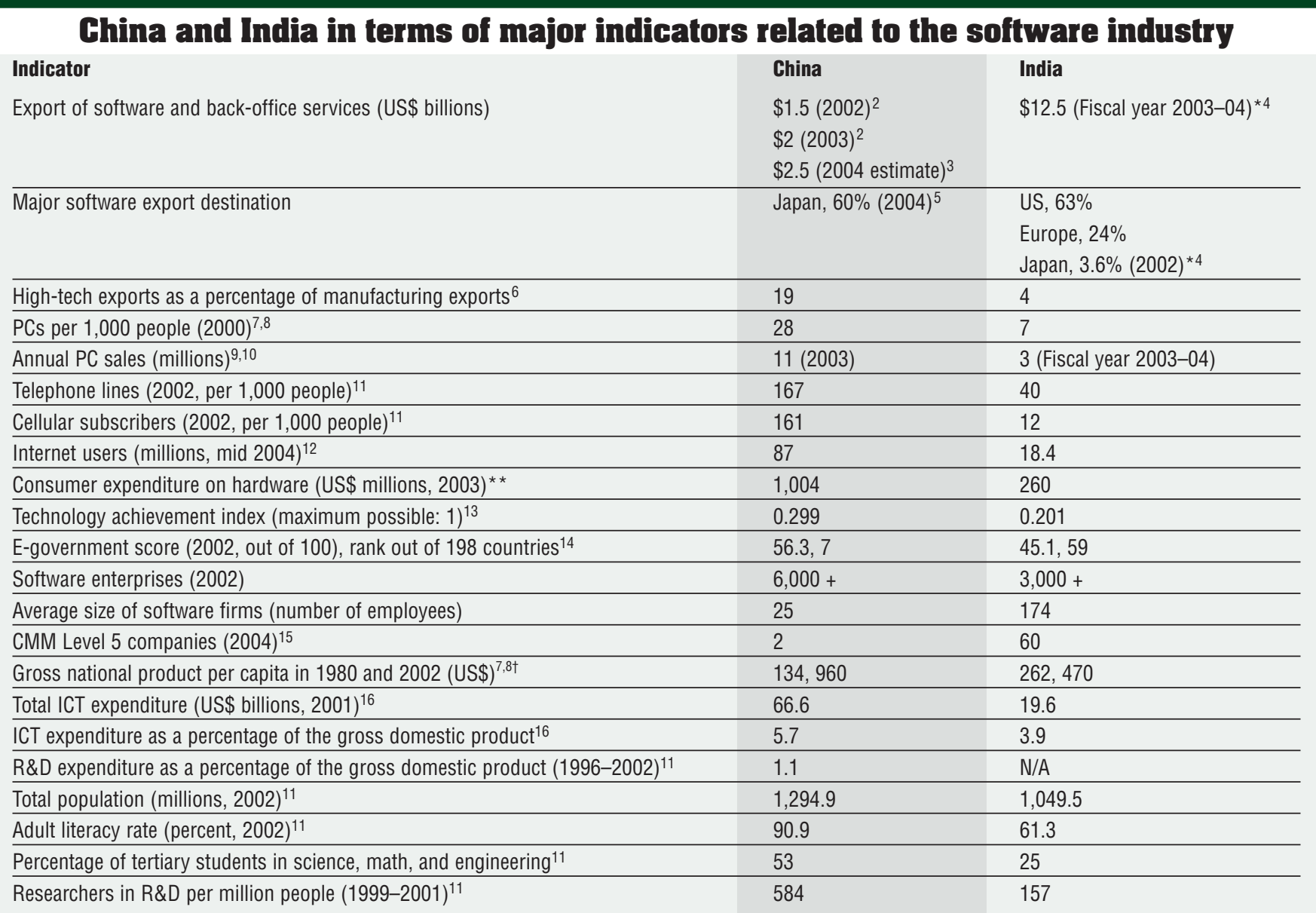

*Software export data are from India's National Association of Software and Service Companies.

${ }^{* *}$ Calculated from Euromonitor International data.

tThe 1980 per capita GDPs are in 1987 US dollars.

China has been working to improve its skill base, its major competitive disadvantage compared to India, the Chinese software industry has also been undergoing major structural shifts in terms of market, participants, technology, focus, and product. These shifts will likely have a significant influence on the gap's magnitude and direction. Analyses that don't consider such factors will likely be too simplistic to make a meaningful prediction.

\section{The structural shifts}

As in any economic sector, companies in the software industry need to realign and adapt to major technological and market changes. ${ }^{19}$ Social, political, and cultural adaptations are equally important. Such adaptation and realignment are tightly linked to a company's success. The Indian software industry doesn't seem to make efforts to realign and adapt to technology and market changes. On the other hand, the Chinese software industry is undergoing major interrelated structural shifts in many respects, thanks mainly to government initiatives.

\section{Market shift: Capturing the domestic market}

One fundamental structural shift is related to stimulating domestic demand and orienting Chinese software firms toward the domestic market. Estimates of China and India's domestic software market sizes vary widely. However, on the basis of related indicators such as electronic industries and penetration rates of major technologies including fixed and cellular telephone lines, PCs, and the Internet (see table 1 ), we can assume that domestic software demand in China is higher and growing more quickly than in India. In 2002, the Chinese business PC software market grew by 20 per- 
cent to reach $\$ 2$ billion. In the $\$ 1$ trillion-plus Chinese economy, the electronics industry exceeded $\$ 130$ billion in 2002 (20 percent of the world market ${ }^{20}$ ) and is estimated to reach $\$ 252$ billion in 2006. India's electronics industry, on the other hand, amounted to $\$ 12.3$ billion in 2002 and is estimated to reach $\$ 35.6$ billion in 2010. China is already the world's second-biggest PC market and is expected to become the biggest by $2010 .{ }^{21}$

Recent institutional changes are stimulating domestic software demand in China. China's new piracy law has increased domestic opportunities for software companies. Estimates suggest that over 92 percent of China's software is pirated. ${ }^{22}$ As a World Trade Organization member, China is compelled to adhere to the TRIPS (Trade-Related Aspects of Intellectual Property Rights) agreement. This agreement requires China to provide adequate legal and enforcement tools to prevent piracy. Unlike other new members, China is subject to an annual review of its WTO obligations for the first 10 years of its membership. Many countries will likely put pressure on China to act on intellectual-property infringement. Under new laws, buyers of pirated goods are fined and manufacturers will likely face jail time and equipment confiscation.

More important, Chinese policies are increasingly gravitating toward domestic firms. Although foreign companies have dominated China's domestic software market, domestic vendors are rapidly capturing the Chinese market. In 2003, domestic companies captured 30 percent of the Chinese software market; by 2010, they hope to capture 60 percent. ${ }^{19,23}$

Government software consumption and recently enacted local procurement laws favor domestic players. In all developing countries, the government is the single biggest user of IT products, ${ }^{24}$ and the Chinese government is ahead of other developing-country governments in adopting modern IT. A significant part of China's informatization strategy is the implementation of e-government programs. For instance, China ranked seventh among 198 countries in terms of e-government performance in 2002. In terms of IT adoption, the Chinese government is rated ahead of global high-tech leaders such as Switzerland, the UK, Singapore, and Germany. ${ }^{14}$ Estimates suggest that the government sector accounts for 25 percent of the Chinese software market (www.financialexpress.com/fe_full_story.php? content_id=53682).

The Government Procurement Law, enacted in January 2003, requires government departments to procure domestic goods and services when possible. In early 2002, even before the law's existence, six out of seven government software contracts went to Chinese vendors. Despite China's accession to the WTO, government procurement is excluded from the scope of multilateral trade rules governing the WTO. So, China isn't obliged to open its government procurement to foreigners.

Chinese policies are thus geared toward favoring domestic software manufacturers. Fear of dependence on foreign countries combined with a sense of national pride resulted in the principle of national self-reliance under Mao Tse Tung. Since then, this principle has guided the Chinese economy. Although attitudes toward technology imports and foreign investment have changed drastically, a high level of advocacy for national self-reliance and domestic technology development still exists among Chinese policy makers, researchers, scientists, and especially military leaders. For instance, China is the world's largest maker of DVD players. By adopting its own technology, it could save the $\$ 2$ billion a year in royalties it pays to an 18company consortium. ${ }^{25}$ China is determined to achieve self-reliance and reverse the flow of fees by exporting Chinese standards.

\section{Participant shift: Emergence of new players}

On average, Chinese software companies are much smaller than Indian firms (see table 1). For instance, China's largest company, Oriental Software, has about 1,300 employees compared to 26,000 at India's Infosys and 24,000 at Tata Consulting Systems (TCS). Over half of China's software houses have fewer than 50 employees. ${ }^{26}$ Typical players in the Chinese software industry thus suffer from an absence of management skills and lack of experience working on sophisticated largescale projects. ${ }^{19}$

An important structural shift in the Chinese software landscape has been the emergence of new and powerful players. The Chinese government established Red Flag Linux, backed by the Chinese Academy of Science, in August 1999. Similarly, the government established the Beijing Software Industry Production Center to organize open source software (OSS) de- 
velopment. Building on Red Flag and Cosix Linux and coordinating the efforts of 100 software engineers across 18 organizations, the center launched Yangfan Linux in the early 2002. The operating system was installed in 2,800 government computers in Beijing during the first six months. Yangfan is based on versions of Linux that Red Flag and the China Computer Software Corporation developed. The center also developed office applications and other Linux-based software. In early 2004, the government selected 29 domestic firms and is encouraging them to export software to the US and Europe. ${ }^{27}$

\section{Technology shift: Investment in disruptive innovation}

Another structural shift is the increased emphasis on OSS development and deployment. OSS development was the only software project on a list of the government's top technology priorities in 1999. Similarly, Linux Internet server software and Linux mobile phone software were among the 19 projects that the Ministry of Information Industry identified in 2004 for the IT Fund, which the State Council founded in 1986 to encourage IT R\&D. The IT Fund provides grants to high-technology $\mathrm{R} \& \mathrm{D}$ projects with the potential to foster development in areas identified as strategically important in the Chinese IT industry.

The scale of OSS development and deployment in China is large enough to notice at the global level. In the second half of 2003 alone, Linux sales in the Chinese PC market exceeded 800,000 copies. At this rate, annual Linux sales in the Chinese PC market are over half of the annual PC sales in India (see table 1). In addition to PCs, China's aircraft, weapons systems, vehicles, industrial equipment, and consumer devices already use Red Flag's Linux applications. ${ }^{25}$ Thanks to OSS, the Chinese military has been able to use domestically developed supercomputers. Dawning, a spinoff from the Chinese Academy of Sciences, developed the Dawning 4000L, a supercomputer with over 3 Tflops per second computing power. Dawning 4000L is based on a Chinese-designed Linux OS.

Nearly all major global OSS players, including HP, Intel, Sun, Oracle, and IBM have significant operations in the Chinese Linux industry. In November 2003, Sun announced a deal to sell 200 million copies of the Linux-based
Java Desktop System to the government. Multinational corporations have collaborated with Chinese partners to get a slice of the exponentially growing Chinese Linux market.

No other countries come even close to the level of advancement China has achieved in deploying OSS, particularly Linux. OSS satisfies several characteristics of a disruptive innovation in the software industry. Despite inferior initial performance, disruptive innovations are generally "cheaper, simpler, smaller, and more convenient to use" than established products and services in mainstream markets. ${ }^{28}$ OSS has experienced initial compatibility problems; many OSS and Windows applications don't work on each other's platforms, and OSS users often encounter compatibility issues with their business partners' standards or client needs. However, OSS has a lower initial cost, slower obsolescence of basic infrastructure features, and thus a lower total cost of ownership. Its amenability to modification makes localized customization easier. OSS communities provide supportive environments for transition. OSS has high levels of compatibility and portability for old and used hardware. ${ }^{29}$ These disruptive characteristics will likely establish an entirely new performance trajectory for OSS.

Disruptive innovations either create new markets by targeting nonconsumers or compete in the low end of an established market. Given limited computerization in developing countries, most firms and individuals are currently nonconsumers of software. Developing countries have historically been locked out of high-tech industries because they lacked skills and wealth. The demand for software in these markets is typically small and hence unattractive to large companies such as Microsoft, IBM, Oracle, and SAP.

Open source software's disruptive characteristics will likely make it attractive for developing countries. As with other disruptive innovations, the incumbents (for example, Indian software firms and software giants from developed countries) might lack the ability to play in the new game in the field of OSS. ${ }^{28}$ What's more, by creating new consumption and improving the available offerings, innovators might also attract incumbents' customers. So, China's competitive edge in OSS will likely result in Chinese firms' emergence as a powerful threat to incumbents in the global software industry.
No other countries come even close to the level of advancement China has achieved in deploying OSS, particularly Linux. 
Focus shift: Collaboration and concentration on core competence

Chinese companies have collaborated with multinational corporations and governments in other Asian economies on various software projects. Such collaboration promotes synergy and lets Chinese firms focus on core competence. For instance, Red Flag has collaborated with

- TurboLinux to introduce Chinese-language versions of Linux;

- Miracle Linux to develop Linux versions of Oracle's database software and Asianux (a just-for-Asia Linux);

- HP to port HP's Integrity and Proliant servers to Red Flag Linux;

- the US company LinuxLab to develop and market software;

- Eforce, Culturecom, and Mobile Telecom to develop the Chinese 2000 Mobile Linux Operating System for handheld devices; and

- Oracle to develop Red Flag Data Center OS4.0.

Similarly, the Chinese Academy of Science's Chinese Software Institute launched Hongqi Linux, an all-Chinese operating system, and collaborated with Compaq for developing application solutions in August 1999. The institute also launched Chinese Penguin64 with Singapore's Donovan Systems in 2000. Likewise, Motorola collaborated with Lineo, which developed embedded Linux, and Caldera, which provides Linux for commercial applications. IBM has an alliance with Kingsoft, China's biggest office-automation software vendor, to develop desktop Linux applications. Red Flag is also working with companies such as HP to develop OSS products for international markets.

China has also identified regional economies with similar missions and collaborated with their governments and technology firms on numerous software projects. The Japan-ChinaKorea (JCK) open source alliance, announced in November 2003, is an initiative to promote OSS by co-sourcing. The Japanese IT Services Industry Association, the Chinese Software Industry Association, and the Federation of Korean Information Industries are guiding the JCK alliance. The three associations have over 1,000 corporations as members, including nearly all major players in the Japanese and
Korean IT industries. The JCK partnership is working on open source business models, standardizing software, and training software engineers. There has been a division of labor in the partnership: China will develop PC operating systems, Japan will focus on software development and security, and Korea will develop software for PDAs. ${ }^{30}$ The partnership is setting up a database to coordinate efforts and avoid duplication.

\section{Product shift: Bundling with hardware and software}

As I noted earlier, China's high-tech sector is far ahead of India's and has a wider global presence. High-tech products accounted for 19 percent of China's manufactured exports in 2001, compared to India's four percent (see table 1). In 2001, China exported over \$24 billion in IT hardware, compared to India's $\$ 1$ billion. ${ }^{31}$ China's high-tech exports grew by 25.4 percent in 2001 to reach $\$ 46.5$ billion. ${ }^{32}$ China can capitalize on its leadership in the electronics industry and collaboration with global software giants to add value by bundling its software with hardware and software manufactured by foreign companies. Given that devices from cars to coffee pots and supercomputers to cell phones use OSS, adding value by bundling seems promising for the Chinese software industry.

Bundling with cell phones. Consider the Chinese third generation (3G) mobile standard Time Division-Synchronous Code Division Multiple Access. TD-SCDMA is the only International Telecommunications Unionapproved 3G standard of the Time Division Duplex mode and uses the $3 \mathrm{G}$ frequencies that the ITU allocated to TDD. TD-SCDMA is more suited than competing standards for use in the dense cities common in developing countries. Estimates suggest that it will capture a significant share of the global market following its launch in 2005..$^{33}$ In July 2004, Datang Telecom Technology, the intellectualproperty owner of TD-SCDMA, confirmed that it had selected Linux as its $3 \mathrm{G}$ handset's operating system.

Bundling with PCs. The Chinese desktop PC industry is more advanced than those in other developing countries. According to the IDC's 2003 Chinese PC market report, the Chinese com- 
pany Legend is the leader in the Chinese desktop PC market, with a market share of 27.8 percent in 2002. ${ }^{34}$ Legend's subsidiary is already selling motherboards and other hardware and accessories in Europe and Asia. In the long term, the company aspires to become international and aims to increase its out-of-China sales to 30 percent of total sales by $2006 .^{34}$ Some players from emerging economies are selling PCs that use open source operating systems and applications. For example, LG, a Korean multinational corporation, has successfully employed such a strategy. LG is exporting Pentium 4 PCs to India that are low-priced because they use Red Hat 8 Linux. This low price has boosted demand for LG's PCs in India.

Bundling with other software. Bundling Chinese software with that of multinational corporations benefits both parties. The success of a complementary program that runs on OSS, such as Linux, will boost demand for some technology products, and multinational corporations' expertise in such products boosts demand for their offerings. ${ }^{35}$ Such bundling has already occurred for the domestic market. For instance, IBM signed a marketing agreement with Red Flag to bundle IBM DB2 Express Database software with Red Flag Linux for use by small and medium-sized businesses.

\section{Overcoming the competitive disadvantage}

China is also finding ways to overcome its competitive disadvantage by removing the skill bottleneck. Despite a lack of human resources and competence in the software sector, China is ahead of India in terms of basic indicators such as the concentration of researchers in $\mathrm{R} \& \mathrm{D}$, proportion of tertiary students in math and engineering, and literacy rate (see table 1). In addition, the Chinese government has formulated policies to attract Chinese science and technical workers living abroad and use them as a national competitive advantage. Among foreign-born scientists and engineers working in the US, more originate from China than any other country. Thanks to increased domestic opportunities, a higher proportion of Chinese engineers trained in advanced countries are returning to China. For instance, an estimated 75 percent of Chinese engineering students who graduate in the US return to China, compared to 25 percent in the past. ${ }^{36}$
In terms of linguistic skills, China has a large population with good command of Asian languages such as Japanese and Korean. They can overcome poor English with training and experience. ${ }^{37}$ Students in Chinese schools learn English, and college students must pass English proficiency exams to graduate. In 2002, 20 million people were undergoing English language training in China.

To combat a lack of high-level international quality certification, such as higher CMM levels. China is also attempting to enhance its technological skills. For instance, the Chinese government is providing incentives for software firms that attain CMM Level 3 or higher. ${ }^{26}$ Likewise, in an attempt to improve the OSS skill base, China has recently made OSS a required course in 35 universities and 35 prevocational schools.

\section{Where is the future leading?}

As we've seen, the magnitude and direction of the future gap between China and India's software industries are functions of OSS's degree of disruptiveness, the success of collaborative efforts with multinational corporations and at the regional level, China's capability to develop the domestic technological base (for example, TD-SCDMA's success), the Chinese electronics industry's international performance, and the Chinese software market's domestic growth.

\section{Attacking competitors' markets}

China and India's major software destinations are related to cultural distance. The US and the UK are India's major markets, thanks to its English language competence (see tables 1 and 2). On the other hand, China's cultural similarity to Japan and South Korea has facilitated its software export. Hong Kong-based enterprises are also outsourcing software to mainland China because of geographic proximity and political links. Although small, Japan is much safer than the EU and US for Chinese software firms. China's engagement in regional collaborations such as the JCK initiatives will likely facilitate better customer relationships and further strengthen the market.

Compared to Indian software giants such as Infosys and TCS, Chinese companies are smaller and less known in the global market. Language and cultural barriers compound the problem for Chinese firms in the US and EU
China is also finding ways to ouercome its competitive disaduantage by remouing the skill bottleneck. 


\section{Trable 2}

\section{Market sizes of Ghina and India's major software destinations*}

\begin{tabular}{|c|c|c|c|}
\hline Country & Software category & Market size ${ }^{* *}$ (2002) & Remarks \\
\hline \multirow[t]{5}{*}{ USA } & Business PCs & $8,402.9$ & $\begin{array}{l}\text { The US is the world's largest software market and accounted for half } \\
\text { the world's software sales in the past decade. Moreover, American IT } \\
\text { and financial services companies have geared up much faster than their } \\
\text { European counterparts to exploit offshore programming's advantages. } \\
\text { Chinese firms are rapidly making inroads to the US. }\end{array}$ \\
\hline & Networking & $3,932.0$ & \\
\hline & Home, leisure, and entertainment PCs & $4,500.2$ & \\
\hline & Multimedia & $6,501.0$ & \\
\hline & Prerecorded music and video & $34,515.5$ & \\
\hline \multirow[t]{5}{*}{$\overline{\mathrm{UK}}$} & Business PCs & $1,640.0$ & $\begin{array}{l}\text { Among Western European countries, the UK is India's largest software } \\
\text { destination. India's former colonization by Great Britain and Indians' } \\
\text { English language advantage facilitate software demand from the UK. }\end{array}$ \\
\hline & Networking & 820.5 & \\
\hline & Home, leisure, and entertainment PCs & 595.6 & \\
\hline & Multimedia & 608.0 & \\
\hline & Prerecorded music and video & $3,407.9$ & \\
\hline Japan & Business PCs & $6,000.0$ & $\begin{array}{l}\text { Language and cultural barriers are hindering the growth of India's } \\
\text { exports to Japan. }\end{array}$ \\
\hline South Korea & Business PCs & 218.0 & \\
\hline
\end{tabular}

markets. As I mentioned earlier, only a few government-selected firms are focusing on the US and EU markets.

Although China, according to an IDC study, is the fourth-favorite software-outsourcing location for US companies after India, Canada, and Ireland, ${ }^{27}$ software sales from Chinese firms to the US market are only a fraction of Indian firms' sales. In 2003, only 18 percent of China's software-outsourcing sales came from the US. ${ }^{27}$ Chinese companies are focusing on US-invested companies in China rather than directly competing with Indian firms. ${ }^{27}$ Nevertheless, because the US and EU are major buyers of China's hardware, the structural shifts I discussed earlier (for example, bundling) can facilitate software's penetration in these economies.

\section{Developing countries' markets}

The software market is growing fast in developing countries. Although Indian software firms export to over 95 countries, less than 10 percent of those exports go to countries outside the US, the EU, and Japan (see tables 1 and 2). India thus has a limited presence in developing countries. China's electronics exports to developing countries and increased bundling with hardware will help boost China's commercial software growth. Moreover, almost all major developing countries in Asia, Africa, and Latin America are rapidly gravitating towards OSS and have high-profile national OSS projects. They're thus likely to favor open source over proprietary software. OSS's lower total cost of ownership combined with China's increasing dominance in the global IT industry, therefore, will let China significantly alter the dynamics of its competition with India.

I ndia has outperformed China in terms of skill base and has an established track record and a solid customer base. For instance, over one-fifth of Fortune 1,000 companies outsource their software requirements to India. Moreover, the US and the EU, India's major software destinations, have much higher software demand than Japan, China's major software destination (see table 2).

However, unlike India's one-dimensional development that focuses solely on the skill base (for example, the number of CMM Level 5 
companies and the size of the technicalmanpower pool), China has been undergoing major structural changes and multidimensional development. The structural shifts could dramatically reshape the Chinese software industry and change the competitive landscape.

\section{References}

1. D. Farrell, P. Gao, and G.R. Orr, "Making Foreign Investment Work for China,” McKinsey Ouarterly, 2004 Special Edition: China Today, www.mckinseyquarterly. com/ab_g.aspx? ar $=1470 \& L 2=7 \& L 3=8$.

2. "Shanghai to Hold Global IT Outsourcing Summit," Sino Cast China Business Daily News, 15 Oct. 2003, p. 1.

3. "China's Software Sales to Reach $\$ 210$ Billion in 2004," SinoCast China Business Daily News, 12 Jan. 2004, p. 1.

4. "India's Software Exports Reach \$12.5 Billion," World IT Report, 6 June 2004, p. 1.

5. "Chinese Software Vendors Actively Develop Overseas Market," SinoCast China Business Daily News, 21 May 2004, p. 1.

6. Human Development Report 2002, United Nations Development Program, 2002, http://hdr.undp.org/reports/ global/2002/en.

7. World Development Indicators 2004, World Bank Group, www.worldbank.org/data/wdi2004/index.htm.

8. Human Development Report 1997, United Nations Development Program, 1997, http://hdr.undp.org/reports/ global/1997/en.

9. STAT-USA Market Research Report, 24 Feb. 2004, http://strategis.ic.gc.ca/epic/internet/inimr-ri.nsf/en/ gr123374e.html.

10. ZDNet India, "PC Sales Surpass 8-lakh Mark in Q3," 26 Mar. 2004, www.zdnetindia.com/news/national/ stories/366,100636.html.

11. Human Development Report 2004, United Nations Development Program, 2004, http://hdr.undp.org/reports/ global/2004/pdf/hdr04_HDI.pdf.

12. "Internet Usage in Asia," Internet World Stats, 2005, www.internetworldstats.com/stats3.htm.

13. Human Development Report 2001, United Nations Development Program, 2001, http://hdr.undp.org/reports/ global/2001/en/.

14. D.M. West, "Global E-Government," Brown Policy Report, Center for Public Policy, Brown Univ., Sept. 2002, www.insidepolitics.org/egovt02int.PDF.

15. “The Dragon is No Imminent Threat," Businessline, 23 Feb. 2004, p. 1.

16. Promoting ICT for Human Development in Asia 2004, Elsevier, 2004; http://hdrc.undp.org.in/APRI/Publication/ PBriefings/summary.htm.

17. R. Jain, "The Prahalad Prescription," Samachar, 17 Jan. 2002, www.samachar.com/tech/archives/techtalk46. html.

18. B. Einhorn et al., "High Tech in China: Is It a Threat to Silicon Valley?” Business Week, 28 Oct. 2002, www. businessweek.com/magazine/content/02_43/b3805001.htm.

19. N. Kumaresan and K. Miyazaki, "Management and Policy Concerns over Shifts in Innovation Trajectories: The Case of the Japanese Robotics Industry," Technology Analysis \& Strategic Management, vol. 13, no. 3, 2001, pp. 433-462.

20. "China Industry: Software Exports to Expand Rapidly over Next Several Years,” EIU Views Wire, 16 Oct. 2003, http://proquest.umi.com/pqdweb?did=664853981\&sid= 1\&Fmt=3\&clientId=15109\&RQT=309\&VName=PQD.

21. D.Young, "AMD Invades Intel's China Turf," The Boston Globe, 9 June 2004, www.boston.com/business/

\section{Alout the Author}

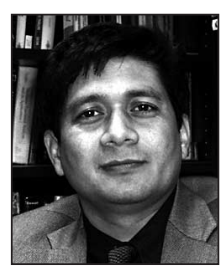

Nir Kshetri is an assistant professor at the University of North Carolina at Greensboro's Bryan School of Business and Economics. His research focuses on the international dimension of IT management and marketing. He received his PhD in business administration from the University of Rhode Island. He's a member of the Pacific Telecommunications Council, the Association for Information Systems, the Academy of International Business, the American Marketing Association, and the Information Resource Management Association. Contact him at the Bryan School of Business and Economics, Univ. of North Carolina at Greensboro, Bryan Bldg., Rm. 368, PO Box 26165, Greensboro, NC 27402-6165; nbkshetr@uncg.edu.

technology/articles/2004/06/09/amd_strikes_chip_deal_ with_chinas_lenovo.

22. M. Kessler, "US Firms: Doing Business in China Tough, but Critical," USA Today, 17 Aug. 2004, p. B01.

23. D. Hale and L.H. Hale, "China Takes Off," Foreign Affairs, vol. 82, no. 6, 2003, pp. 36-54.

24. S.R. Nidumolu et al., "Information Technology for Local Administration Support: The Governorates Project in Egypt," MIS Quarterly, vol. 20, no. 2, 1996, pp. 196-224.

25. D. Calbreath, "China Invents Ways to Avoid Royalties," San Diego Union-Tribune, 22 Feb. 2004, www. signonsandiego.com/uniontrib/20040222/news_ mz1b22china.html.

26. T. Leung, "Gartner: China Needs to Address Software Quality Issue” Asia Computer Weekly, 14 July 2003, p. 1.

27. L. Baijia, "Firms Keen on Software Outsourcing," China Daily, 12 May 2004, www.chinadaily.com.cn/ english/doc/2004-05/12/content_329899.htm.

28. C.M. Christensen, M.E. Raynor, and S.D. Anthony, "Six Keys to Building New Markets by Unleashing Disruptive Innovation,” Harvard Management Update, Harvard Business School, 10 Mar. 2003; http://hbswk. hbs.edu/item.jhtml?id=3374\&t=innovation\&noseek=one.

29. N. Kshetri, "Economics of Linux Adoption in Developing Countries," IEEE Software, vol. 23, no. 1, 2004, pp. $74-81$

30. J. Krikke, "Linux Revolution: Asian Countries Push Open Source," Linux Insider, 17 Dec. 2003, www. linuxinsider.com/story/32421.html.

31. V.V. Nair, “There's No Stopping Them!” Businessline, 15 May 2002, www.blonnet.com/ew/2002/05/15/ stories/2002051500210300.htm.

32. "Rapid Growth of China's High-Tech Exports," People's Daily, 12 Jan. 2002, http://english.peopledaily. com.cn/200201/12/eng20020112_88493.shtml.

33. B. Einhorn, "Master of Innovation? China Aims to Close its Technology Gap with Korea and Japan," Business Week Online, 14 April 2003, www.businessweek. com/magazine/content/03_15/b3828010.htm.

34. “Can China's Legend Go Global?” CNET News, 5 April 2003, http://news.com.com/Can+China's+ Legend+go+global\%3F/2009-1069_3-995529.html.

35. J. Lerner and J. Tirole, "Some Simple Economics of Open Source," J. Industrial Economics, vol. 50, no. 2, 2002, pp. 197-234.

36. J. Flanigan, "China's Technological Ambitions Take Flight," Los Angeles Times, 19 Oct. 2003, p. C1.

37. B. Einhorn and M. Kripalani, "Outsourcing: Make Way for China,” Business Week Online, 11 Aug. 2003; http://businessweek.com/magazine/content/03_31/ b3844132_mz033.htm.

For more information on this or any other computing topic, please visit our Digital Library at www.computer.org/publications/dlib. 
Reproduced with permission of the copyright owner. Further reproduction prohibited without permission. 